\title{
Transport of Protons and Capacitive Properties of the Nylon/Porphyrin/Graphene Oxide Coating
}

\author{
César A. García-Pérez, Carmina Menchaca-Campos, Miguel A. García-Sánchez², Ociel \\ Rodríguez-Pérez ${ }^{1}$ and Jorge Uruchurtu ${ }^{1}$ \\ ${ }^{1}$ Centro de Investigación en Ingeniería y Ciencias Aplicadas-IICBA, Universidad Autónoma del \\ Estado de Morelos, Avenida Universidad 1001, 62209 Cuernavaca, Morelos, México. \\ ${ }^{2}$ Departamento de Química, UAM-Iztapalapa, Avenida San Rafael Atlixco 186, Vicentina, 09340 \\ México, DF, México.
}

\begin{abstract}
Electrochemical impedance (EI) measurements were performed to evaluate the nylon 66/-tetra(para-aminophenyl) porphyrin $\left(\mathrm{H}_{2} \mathrm{~T}\left(p-\mathrm{NH}_{2}\right) \mathrm{PP}\right)$ /graphene oxide $(\mathrm{GO})$ film coating on stainless steel and compared to the nylon/ $\mathrm{H}_{2} \mathrm{~T}\left(p-\mathrm{NH}_{2}\right) \mathrm{PP}$ and nylon/GO film samples using $1 \mathrm{M} \mathrm{H}_{2} \mathrm{SO}_{4}$ as electrolyte. The nylon/ $\mathrm{H}_{2} \mathrm{~T}\left(p-\mathrm{NH}_{2}\right) \mathrm{PP}$ and nylon/GO composite films showed high electrochemical impedance in the order of $10^{9} \mathrm{ohm}-\mathrm{cm}^{2}$ and a system controlled by mass transfer, product of a diffusion process at low frequencies with a resistance up to 5 orders of magnitude, indicating the diffusion of protons through the coating and a decrease in the metal dissolution. Otherwise, the nylon/ $\mathrm{H}_{2} \mathrm{~T}\left(p-\mathrm{NH}_{2}\right) \mathrm{PP} / \mathrm{GO}$ film compound evaluated show good ionic conductivity and electrochemical stability in the acid environment, acting porphyrin as a catalyst to the passage of protons through the film, reducing its electrochemical impedance up to 7 orders of magnitude with respect to the compounds nylon/ $\mathrm{H}_{2} \mathrm{~T}\left(\mathrm{p}-\mathrm{NH}_{2}\right) \mathrm{PP}$ and nylon/GO. Likewise, good capacitance values are also shown by modifying the concentrations of porphyrin and GO reinforcing materials. These properties are important for technological applications, such as anticorrosion coating for bipolar plates or membrane in a fuel cell type PEM, super-capacitors, etc.
\end{abstract}

Keywords: graphene oxide; porphyrin; nylon 66. coating, electrochemical techniques

\section{Introduction}

Electrochemical Impedance Spectroscopy (EIS) has been used in the evaluation of polymer coated metals and their behavior when exposed in different environments, being the aim of this work. Studies that carry out this technique include: evaluation of water uptake, degradation with exposure time or coatings disbondment, estimation of corrosion rates at the metal/coating interface[1] and determination of the active area at which corrosion occurs, as well as evaluation of solar and fuel cell and battery charge-discharge cycles [2] .

In different areas of research, the synthesis or manufacture of composite and hybrid materials has been developed with the purpose of taking advantage of the particular characteristics of the materials that are part of them, as well as their new properties, resulting from the interactions between the different materials. An example is the nylon/ $\mathrm{H}_{2} \mathrm{~T}\left(\mathrm{p}-\mathrm{NH}_{2}\right) \mathrm{PP} / \mathrm{GO}$ compound, which 
according to its properties shown in this work, makes it attractive for use in energy applications such as fuel cells, capacitors, solar cells, etc.

Bipolar plates for polymer electrolyte membrane (PEM) fuel cell are commonly made of graphite for high corrosion resistance; however their manufacturability and durability under vibration are unfavorable if compared with the metal ones[3]. Although the metallic bipolar plates have disadvantages such as metallic corrosion, that cause a reduction in contact resistance and possible fouling of the catalyst and the ionomer [4-6].One possible solution to such drawbacks is coating the bipolar plates[7-9] with nylon/ $\mathrm{H}_{2} \mathrm{~T}\left(p-\mathrm{NH}_{2}\right) \mathrm{PP} / \mathrm{GO}$ composite to prevent metal corrosion and dissolution of the passive layer, as well as improve charge transport and energy transfer through the fuel cell.

In super-capacitors it is seek a longer life, high efficiency in charge and discharge, excellent cycleability ( $>10^{6}$ cycles), ability to provide energy quickly, able to operate in extreme temperature conditions without loss of charge capacity, and the presence of less toxic components [10,11].

The porous materials based on carbon[12-16], the transition metal oxides[17-21]and conducting polymers [22, 23]are some of the electrode materials available used in super-capacitors. Each one of these materials has advantages and disadvantages, therefore, the trend is directed towards the use of hybrid electrodes as the mentioned composite of nylon/ $\mathrm{H}_{2} \mathrm{~T}\left(\mathrm{p}-\mathrm{NH}_{2}\right) \mathrm{PP} / \mathrm{GO}$ which combines the individual beneficial aspects and tries to compensates the limitations for each individual compound.

In the case of a possible application of the above mentioned material as an electrode in super-capacitors, nylon and GO could provide excellent mechanical properties that benefit, longer life and an acceptable cycleability, and on the other hand the porphyrin and GO facilitate energy release quickly favoring system charge and discharge.

\section{Experimental.}

\subsection{Characterization.}

Nylon/GO, nylon/ $\mathrm{H}_{2} \mathrm{~T}\left(p-\mathrm{NH}_{2}\right) \mathrm{PP}$ and nylon/ $\mathrm{H}_{2} \mathrm{~T}\left(p-\mathrm{NH}_{2}\right) \mathrm{PP} / \mathrm{GO}$ compounds were formed by electrospinning process on stainless steel 316 [24] and characterized by EIS in a $1 \mathrm{M} \mathrm{H}_{2} \mathrm{SO}_{4}$ solution.

\subsubsection{Electrochemical Measurement.}

To evaluate coatings on stainless steel, electrochemical impedance (EIS) was performed using a Gamry electrochemical instrument at the open circuit potential, in the frequency interval 100000 to $0.01 \mathrm{~Hz}$ with $\pm 10 \mathrm{mV}$ amplitude using $\mathrm{Ag} / \mathrm{AgCl}_{2}$ reference and graphite auxiliary electrodes.

\subsubsection{Cyclic voltammetry.}

According to the results observed in the EIS, cyclic voltammetry was used to determine the capacitive properties of the nylon/ $\mathrm{H}_{2} \mathrm{~T}\left(\mathrm{p}-\mathrm{NH}_{2}\right) \mathrm{PP} / \mathrm{GO}$ compound at different scanning rates: 5, 10, 20, 50, 100, 200 and $300 \mathrm{mV} / \mathrm{s}$. In these tests, electrodes of the compound nylon/ $\mathrm{H}_{2} \mathrm{~T}\left(\mathrm{p}-\mathrm{NH}_{2}\right) \mathrm{PP} / \mathrm{GO}$ deposited on conductive carbon cloth were used. 


\section{Results.}

\subsection{Characterization by EIS.}

\subsubsection{Characterization by EIS of nylon/GO compound.}

The impedance Bode plots presented in Figure 1a show the total impedance values for the nylon/GO sample at two different concentrations of GO (25 and 50\%) for different times of electrospinning. In all tests where the nylon/GO composites are used, it is observed that a mass transport or diffusion process controls the systems. In the case of stainless steel (blank), the widening of the curve in the phase angle (Fig. 1b) is characteristic of the presence of at least two time constants at medium and low frequencies; the first related to a layer of corrosion products or passive film present on the material metal surface and the second corresponding to the charge transfer process associated with the effect of the capacitance of the ionic double layer, followed by a diffusion process across the electrochemical layer at lower frequencies.

Bode plots present in a similar way features for the nylon/GO system: the presence of three time constants are observed: the first due to the coating, clearly seen in the graph for the phase angle at a frequency round $63 \mathrm{~Hz}$ (enclosed in a rectangle) in Figure 1a and 1b,the second caused by an oxide layer, and the third to the capacitance double layer, followed by a low frequency mass transport or diffusion process produced by the complex coating network, forming a barrier between aggressive electrolyte ions and metal substrate.

If the total impedance module (/Z/) of the nylon/GO film compound is compared with the stainless steel blank (Table 1), it can be seen a significant increase in the total impedance adding up to five orders of magnitude $\left(10^{9}\right)$, indicating a considerable increase in the overall electrochemical impedance response and decrease in the dissolution of the substrate or base material.

\subsubsection{Characterization by EIS of nylon/ $\mathrm{H}_{2} \mathrm{~T}\left(p-\mathrm{NH}_{2}\right) \mathrm{PP}$ compound.}

In the case of nylon/ $\mathrm{H}_{2} \mathrm{~T}\left(p-\mathrm{NH}_{2}\right) \mathrm{PP}$ composite the electrochemical evaluation (Fig.2a and $2 \mathrm{~b}$ ) shows that for longer time of electrospinning, the total impedance is higher. The same phenomenon occurs by modifying the concentration of $5 \mathrm{mg}$ to $100 \mathrm{mg} \mathrm{H} \mathrm{H}_{2} \mathrm{~T}\left(p-\mathrm{NH}_{2}\right) \mathrm{PP}$; this last concentration having the highest total impedance value (Table 1), obtaining better protection of the base material against the aggressive ions from the electrolyte. This compound presents again a mass transport or diffusional process, where that increasing the concentration of $\mathrm{H}_{2} \mathrm{~T}\left(p-\mathrm{NH}_{2}\right) \mathrm{PP}$ displaces the signal to higher frequencies and increases its impedance up to five orders of magnitude. Just like the nylon/GO composite, the nylon/ $\mathrm{H}_{2} \mathrm{~T}\left(\mathrm{p}-\mathrm{NH}_{2}\right) \mathrm{PP}$ composite shows a signal dispersion at a frequency around $63 \mathrm{~Hz}$ (enclosed in a rectangle in Fig. $2 \mathrm{~b}$ ) associated with the first time constant (coating resistance). A general quantitative range for a good coating was shown to be $>10^{8} \mathrm{ohm} . \mathrm{cm}^{2}[25]$; in the present study it can be said that the compounds nylon/ $\mathrm{H}_{2} \mathrm{~T}\left(p-\mathrm{NH}_{2}\right) \mathrm{PP}$ and nylon/GO with $\approx 10^{9}$ $\mathrm{ohm} . \mathrm{cm}^{2}$ values have good properties as an anticorrosive coating barrier for stainless steel in an acid environment. 

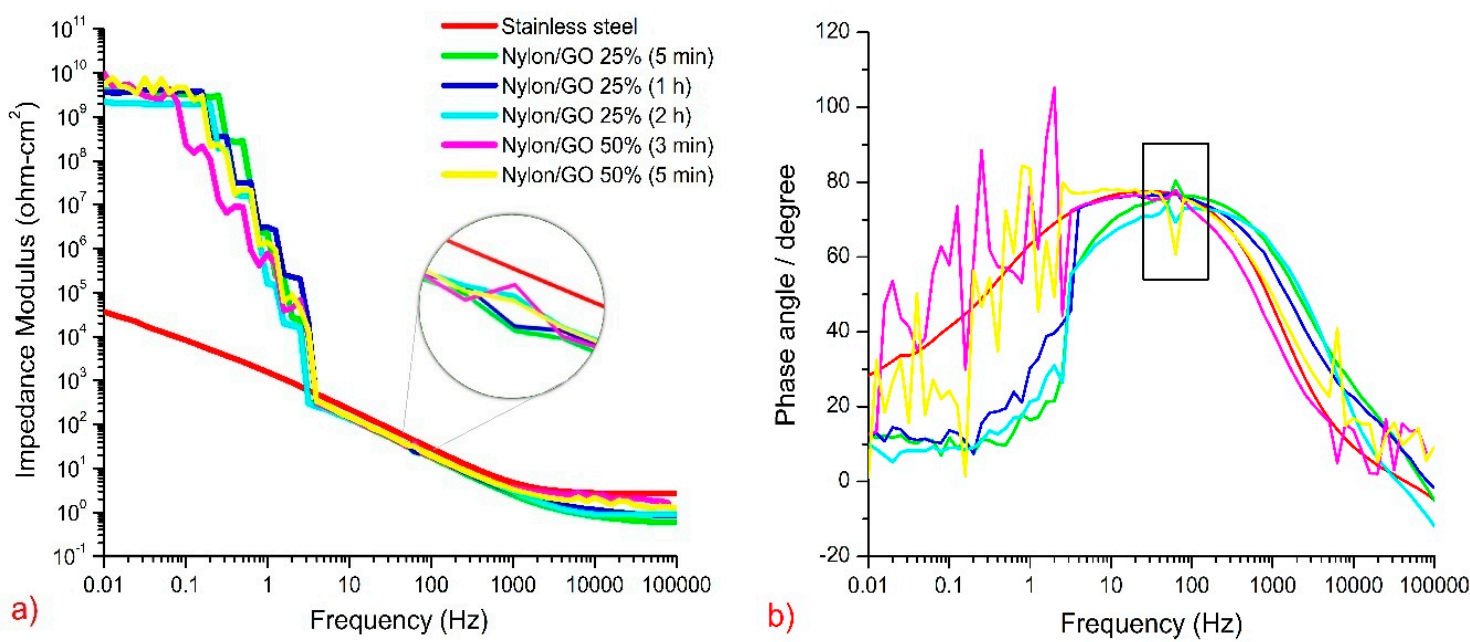

Figure 1.EIS electrochemical evaluation a) Bode and b)phase angle plots of the electrospinning nylon/GO systems $25 \%$ and $50 \%$ of $\mathrm{GO}$ in a $1 \mathrm{M} \mathrm{H}_{2} \mathrm{SO}_{4}$ solution at different electrospinning times.
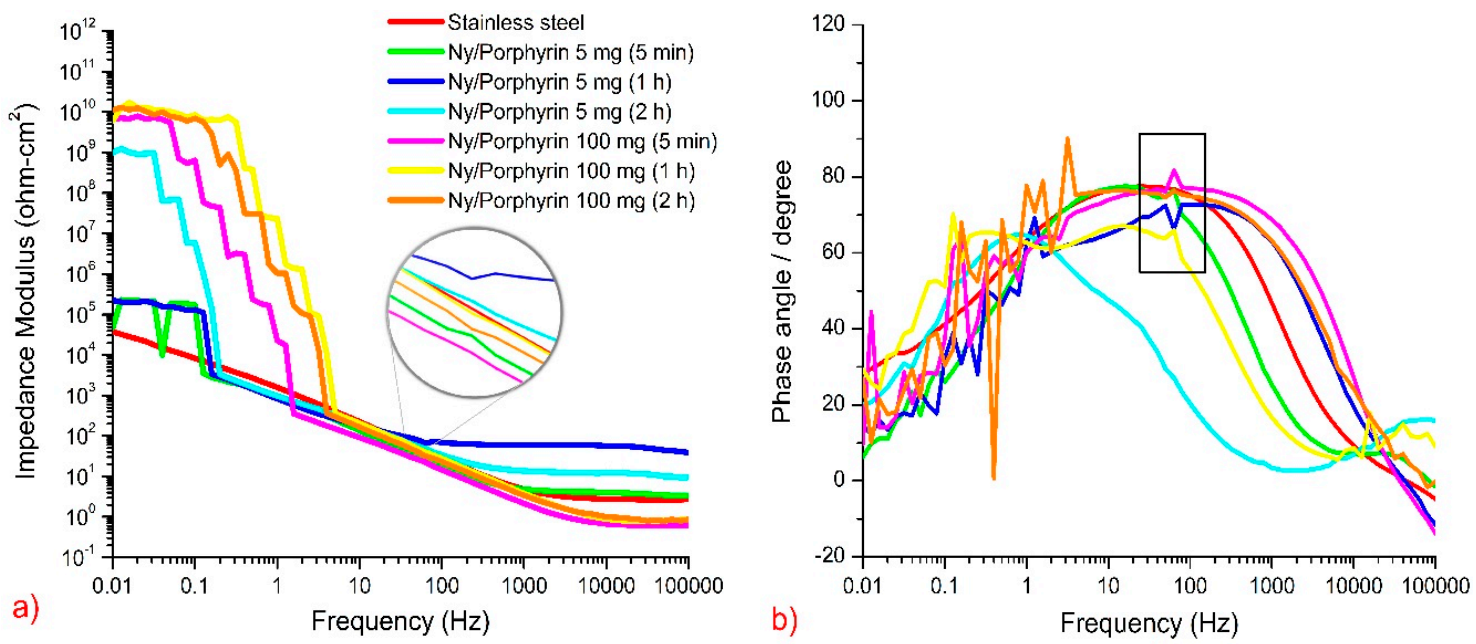

Figure 2. EIS electrochemical evaluation a) Bode and b)phase angle of the nylon/ $\mathrm{H}_{2} \mathrm{~T}\left(p-\mathrm{NH}_{2}\right) \mathrm{PP}$ systems with $5 \mathrm{mg}$ and $100 \mathrm{mg}$ of $\mathrm{H}_{2} \mathrm{~T}\left(p-\mathrm{NH}_{2}\right) \mathrm{PP}$ in a $1 \mathrm{M} \mathrm{H}_{2} \mathrm{SO}_{4}$ solution at different electrospinning times.

\subsubsection{Characterization by EIS of nylon/ $\mathrm{H}_{2} \mathrm{~T}\left(p-\mathrm{NH}_{2}\right) \mathrm{PP} / \mathrm{GO}$ compound.}

After no significant change was detected with increasing concentration of GO from $25 \%$ to $50 \%$,it was decided to use $25 \%$ of GO and only vary the concentration of $5 \mathrm{mg}$ to $100 \mathrm{mg} \mathrm{of} \mathrm{H}_{2} \mathrm{~T}(p-$ $\mathrm{NH}_{2}$ )PP as well as electrospinning time from 5 minutes, to 1 and 2 hours. 
The results of the evaluation by electrochemical impedance spectroscopy for nylon/ $\mathrm{H}_{2} \mathrm{~T}(p$ $\mathrm{NH}_{2}$ )PP/GO composite (Fig.3a and $3 \mathrm{~b}$ ), in the presence of both $\mathrm{GO}$ and porphyrins, a significant decrease in the total impedance of approximately 6 orders of magnitude is shown, as well as reduction ofthe mass transport process present in the nylon/ $\mathrm{H}_{2} \mathrm{~T}\left(p-\mathrm{NH}_{2}\right) \mathrm{PP}$ and nylon/GO systems. It went from a diffusion, to a charge transfer controlled process. This phenomenon may be due to the synergistic effect that occurs between the $\mathrm{H}_{2} \mathrm{~T}\left(p-\mathrm{NH}_{2}\right) \mathrm{PP}$ and $\mathrm{GO}$ intricate barrier structure formed, reducing the total impedance two orders of magnitude compared with the blank sample and therefore, greatly increasing the ionic conductivity of the system.

In Figure 3a,it can be seen that the total impedance in the nylon/ $\mathrm{H}_{2} \mathrm{~T}\left(p-\mathrm{NH}_{2}\right) \mathrm{PP} / \mathrm{GO}$ systems are a function of the concentration ratio of $\mathrm{H}_{2} \mathrm{~T}\left(p-\mathrm{NH}_{2}\right) \mathrm{PP}$, causing that a higher concentrations and longer electrospinning times, induces lower total impedance modulus (/Z/) (see table 1).

The graphical representation of the phase angle shows the presence of three distinctive time constants for all cases where the nylon/ $\mathrm{H}_{2} \mathrm{~T}\left(p-\mathrm{NH}_{2}\right) \mathrm{PP}(5 \mathrm{mg}) / \mathrm{GO}$ (Fig. 3a) compound is used (see experimental section). The first due to the coating, with low resistance values (table 1), the second is due to the formation of a protective passive oxide layer on the metal surface and the third corresponding to a charge transfer process associated with the effect of the capacitance of the ionic double layer.

In the nylon/ $\mathrm{H}_{2} \mathrm{~T}\left(\mathrm{p}-\mathrm{NH}_{2}\right) \mathrm{PP}(100 \mathrm{mg}) / \mathrm{GO}$ (fig. $\left.3 \mathrm{~b}\right)$ systems it was observed that when the electrospinning time rose from 5 minutes to 2 hours, the area under the curve of the Bode phase angle response diminished, maybe due to the change and decrease of the values in the time constants.
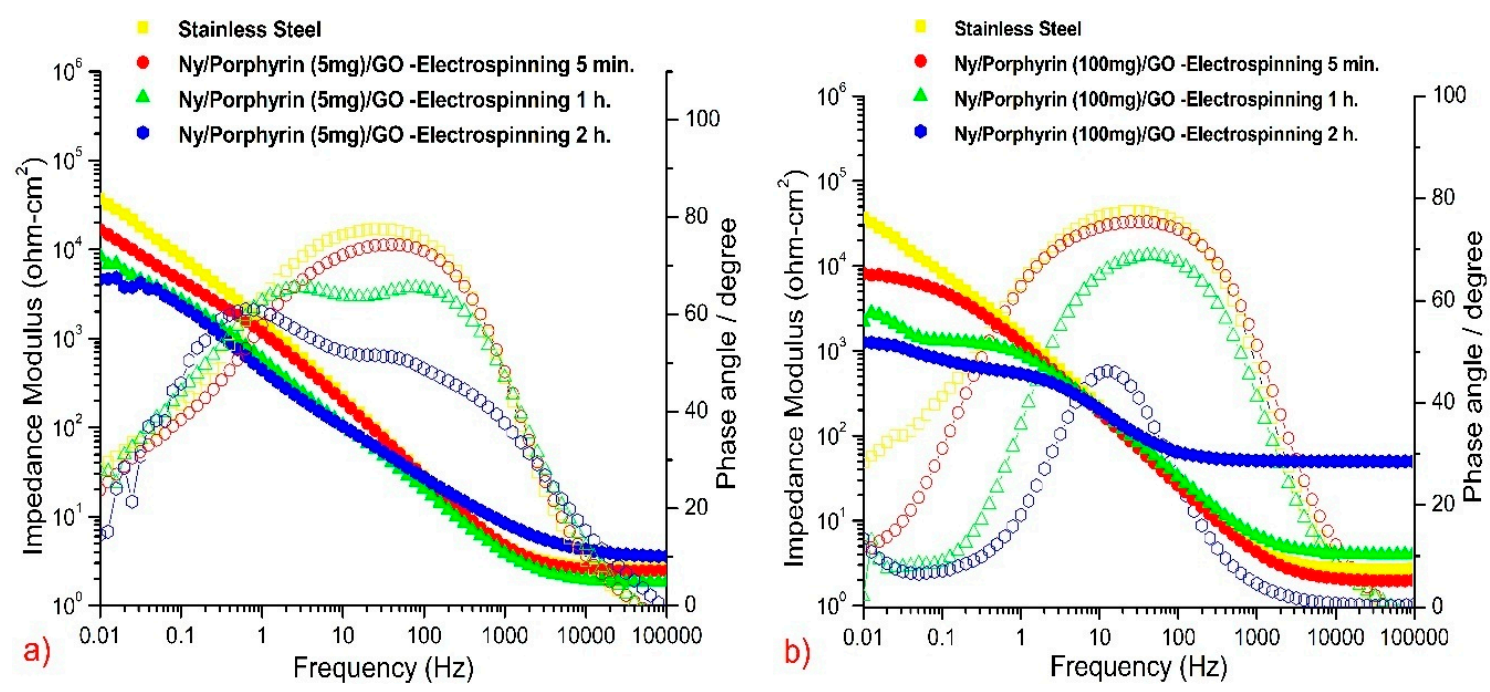

Figure 3. EIS Bode and phase angle electrochemical evaluation, of the a) nylon/ $\mathrm{H}_{2} \mathrm{~T}\left(p-\mathrm{NH}_{2}\right) \mathrm{PP}$ $(5 \mathrm{mg}) / \mathrm{GO}(25 \%)$ and b) nylon/ $\mathrm{H}_{2} \mathrm{~T}\left(p-\mathrm{NH}_{2}\right) \mathrm{PP}(100 \mathrm{mg}) / \mathrm{GO}(25 \%)$ in a $1 \mathrm{M} \mathrm{H}_{2} \mathrm{SO}_{4}$ solution at different electrospinning times.

The corresponding equivalent circuit for nylon/ $\mathrm{H}_{2} \mathrm{~T}\left(p-\mathrm{NH}_{2}\right) \mathrm{PP}$ and nylon/GO systems is presented in Figure 4, in agreement to the observed physical phenomenon, represented by an initial resistance $\mathrm{R}_{\Omega}$ that corresponds to the solution resistance, followed by the pore or coating resistance ( $\left.\mathrm{R}_{\text {pore }}\right)$ and capacitance $\left(\mathrm{C}_{\text {pore }}\right)$, a film resistance $\left(\mathrm{R}_{\text {film}}\right)$ and a capacitance $\left(\mathrm{C}_{\text {film}}\right)$ representing the corrosion products or passive film formed in the metal surface, then in parallel a loop of charge transfer 
resistance $\left(R_{\mathrm{ct}}\right)$ and double layer capacitance $\left(\mathrm{C}_{\mathrm{dl}}\right)$ representing the metal interface, ending with the representation of the diffusional impedance or Warburg process observed during the test $(\mathrm{W})$. The nylon/ $\mathrm{H}_{2} \mathrm{~T}\left(p-\mathrm{NH}_{2}\right) \mathrm{PP} / \mathrm{GO}$ system shows the same components mentioned above in its circuit with the exception of the diffusional process (W) (Fig. 4).

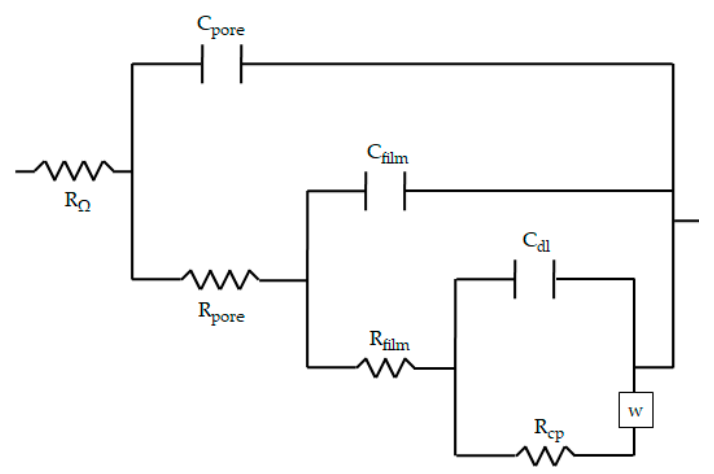

Figure 4. Equivalent circuit for nylon/GO and nylon/ $\mathrm{H}_{2} \mathrm{~T}\left(\mathrm{p}-\mathrm{NH}_{2}\right) \mathrm{PP}$ systems.

Table 1. Experimental data of electrochemical impedance spectroscopy (EIS) of the nylon/ $\mathrm{H}_{2} \mathrm{~T}(p$ $\left.\mathrm{NH}_{2}\right) \mathrm{PP}$, nylon/GO and nylon/ $\mathrm{H}_{2} \mathrm{~T}\left(p-\mathrm{NH}_{2}\right) \mathrm{PP} / \mathrm{GO}$ systems.

\begin{tabular}{|c|c|c|c|c|c|c|c|c|c|c|c|}
\hline Samples & $\begin{array}{c}/ \mathrm{Z} / \\
\left(\Omega . \mathrm{cm}^{2}\right)\end{array}$ & $\begin{array}{l}\mathbf{R}_{\mathrm{s}} \\
(\Omega)\end{array}$ & $\begin{array}{c}R_{\text {pore }} \\
\left(\Omega . \mathrm{cm}^{2}\right) \\
\end{array}$ & $\begin{array}{c}C_{\text {pore }} \\
\left(\mathrm{F} / \mathrm{cm}^{2}\right)\end{array}$ & $\begin{array}{c}\boldsymbol{R}_{\text {film }} \\
\left(\Omega \cdot \mathrm{cm}^{2}\right)\end{array}$ & $\begin{array}{c}\mathrm{C}_{\text {film }} \\
\left(\mathrm{F} / \mathrm{cm}^{2}\right) \\
\end{array}$ & $\begin{array}{c}R_{\mathrm{ct}} \\
\left(\Omega \cdot \mathrm{cm}^{2}\right) \\
\end{array}$ & $\begin{array}{c}\mathrm{C}_{\mathrm{dl}} \\
\left(\mathrm{F} / \mathrm{cm}^{2}\right)\end{array}$ & $\begin{array}{c}\mathbf{R} W \\
\left(\mathbf{\Omega} \cdot \mathrm{Cm}^{2}\right) \\
\end{array}$ & $\begin{array}{c}\mathrm{CW} \\
\left(\mathbf{F} / \mathrm{cm}^{2}\right)\end{array}$ & $\begin{array}{l}C_{\text {Total }} \\
\left(\mathrm{F} / \mathrm{cm}^{2}\right) \\
\end{array}$ \\
\hline Blank (SS) & 36785.8 & 2.7 & -- & --- & 4338.8 & $1.4 \mathrm{E}-04$ & 9141.9 & $3.4 \mathrm{E}-04$ & $2.3 \mathrm{E}+04$ & $6.8 \mathrm{E}-04$ & 4.3E-04 \\
\hline $\begin{array}{c}\mathrm{Ny} / \mathrm{PP} 5 \mathrm{mg} \\
(5 \mathrm{~min})\end{array}$ & 4.7E+04 & 3.35 & 28.75 & 8.7E-05 & 343.6 & $1.4 \mathrm{E}-04$ & 3158.7 & 4.2E-04 & $4.4 \mathrm{E}+04$ & $3.6 \mathrm{E}-04$ & 3.3E-04 \\
\hline $\begin{array}{c}\text { Ny/PP5mg } \\
\text { (1h) }\end{array}$ & $2.2 \mathrm{E}+05$ & 38.9 & 67.9 & 3.7E-05 & 128.2 & $1.9 \mathrm{E}-04$ & 3113.7 & 3.2E-04 & $2.2 \mathrm{E}+05$ & 7.2E-05 & 7.1E-05 \\
\hline $\begin{array}{l}\text { Ny/PP5mg } \\
(2 \mathrm{~h})\end{array}$ & $1.0 \mathrm{E}+09$ & 9.41 & 55.2 & 5.6E-05 & 466.3 & 1.3E-04 & 3231.1 & 2.6E-04 & $1.0 \mathrm{E}+09$ & $1.6 \mathrm{E}-08$ & $1.6 \mathrm{E}-08$ \\
\hline $\begin{array}{l}\mathrm{Ny} / \mathrm{PP} 100 \mathrm{mg} \\
\quad(5 \mathrm{~min})\end{array}$ & $6.6 \mathrm{E}+09$ & 0.62 & 22.19 & $1.1 \mathrm{E}-04$ & 104.3 & $2.4 \mathrm{E}-04$ & 243.6 & 4.1E-04 & $6.6 \mathrm{E}+09$ & 2.4E-09 & 2.4E-09 \\
\hline $\begin{array}{c}\text { Ny/PP100mg } \\
\text { (1h) }\end{array}$ & $6.0 \mathrm{E}+09$ & 0.87 & 40.7 & $6.1 \mathrm{E}-05$ & 73.0 & $1.1 \mathrm{E}-04$ & 242.5 & 1.3E-04 & $6.1 \mathrm{E}+09$ & 2.6E-09 & 2.6E-09 \\
\hline $\begin{array}{c}\text { Ny/PP100mg } \\
(2 \mathrm{~h})\end{array}$ & $1.1 \mathrm{E}+10$ & 0.86 & 31.75 & 7.8E-05 & 78.2 & $1.3 \mathrm{E}-04$ & 259.9 & $1.5 \mathrm{E}-04$ & $1.1 \mathrm{E}+10$ & 1.4E-09 & 1.4E-09 \\
\hline $\begin{array}{c}\mathrm{Ny} / \mathrm{GO} 25 \% \\
(5 \mathrm{~min})\end{array}$ & $4.0 \mathrm{E}+09$ & 0.6 & 22.65 & $1.1 \mathrm{E}-04$ & 49.8 & $1.6 \mathrm{E}-04$ & 236.2 & 2.1E-04 & $4.1 \mathrm{E}+09$ & 3.9E-09 & 3.9E-09 \\
\hline $\begin{array}{c}\mathrm{Ny} / \mathrm{GO} 25 \% \\
\text { (1h) }\end{array}$ & $3.6 \mathrm{E}+09$ & 0.85 & 23.49 & $1.0 \mathrm{E}-04$ & 52.1 & $1.5 \mathrm{E}-04$ & 233.1 & 1.7E-04 & $3.7 \mathrm{E}+09$ & 4.3E-09 & 4.3E-09 \\
\hline $\begin{array}{c}\mathrm{Ny} / \mathrm{GO} 25 \% \\
(2 \mathrm{~h})\end{array}$ & $2.2 \mathrm{E}+09$ & 0.92 & 32.2 & 7.8E-05 & 60.6 & $1.6 \mathrm{E}-04$ & 209.5 & $2.4 \mathrm{E}-04$ & $2.2 \mathrm{E}+09$ & 7.1E-09 & 7.1E-09 \\
\hline $\begin{array}{c}\text { Ny/GO50\% } \\
\text { (3min) }\end{array}$ & $9.9 \mathrm{E}+09$ & 1.64 & 35.29 & 7.1E-05 & 27.1 & 2.3E-04 & 247.8 & $1.6 \mathrm{E}-04$ & $9.9 \mathrm{E}+09$ & $1.6 \mathrm{E}-09$ & $1.6 \mathrm{E}-09$ \\
\hline $\begin{array}{l}\text { Ny/GO50\% } \\
\text { (5min) }\end{array}$ & $5.5 \mathrm{E}+09$ & 1.21 & 33.46 & 9.5E-05 & 36.1 & $1.9 \mathrm{E}-04$ & 239.7 & $1.4 \mathrm{E}-04$ & $5.5 \mathrm{E}+09$ & 2.9E-09 & 2.9E-09 \\
\hline $\begin{array}{c}\text { Ny/PP5mg/ } \\
\text { GO25\%(5min) }\end{array}$ & 16655.4 & 2.45 & 4.73 & 3.3E-05 & 107.3 & 7.3E-05 & 16540.8 & $2.4 \mathrm{E}-04$ & --- & --- & $9.5 \mathrm{E}-04$ \\
\hline $\begin{array}{l}\text { Ny/PP5mg/ } \\
\text { GO25\%(1h) }\end{array}$ & 8375.6 & 1.84 & 4.52 & 4.4E-05 & 33.9 & $1.2 \mathrm{E}-04$ & 8335.2 & $4.9 \mathrm{E}-04$ & --- & --- & 1.9E-03 \\
\hline $\begin{array}{l}\mathrm{Ny} / \mathrm{PP} 5 \mathrm{mg} / \\
\mathrm{GO} 25 \%(2 \mathrm{~h})\end{array}$ & 4676.4 & 3.58 & 3.74 & $1.3 \mathrm{E}-06$ & 51.5 & $1.2 \mathrm{E}-04$ & 4617.6 & $3.4 \mathrm{E}-04$ & --- & --- & $3.4 \mathrm{E}-03$ \\
\hline
\end{tabular}




\begin{tabular}{|c|c|c|c|c|c|c|c|c|c|c|c|}
\hline $\begin{array}{l}\text { Ny/PP100mg/ } \\
\text { GO25\%(5min) }\end{array}$ & 8141.1 & 1.97 & 4.26 & 7.4E-06 & 104.1 & 8.1E-05 & 8030.8 & $6.6 \mathrm{E}-04$ & --- & --- & $1.9 \mathrm{E}-03$ \\
\hline $\begin{array}{c}\text { Ny/PP100mg/ } \\
\text { GO25\%(1h) }\end{array}$ & 2241.8 & 3.95 & 1.23 & $1.6 \mathrm{E}-05$ & 1220.7 & $4.1 \mathrm{E}-04$ & 1015.8 & 3.9E-03 & --- & --- & 7.1E-03 \\
\hline $\begin{array}{l}\text { Ny/PP100mg/ } \\
\text { GO25\%(2h) }\end{array}$ & 1253.5 & 49.9 & 0.85 & $1.4 \mathrm{E}-04$ & 547.9 & 4.4E-04 & 654.8 & 7.4E-03 & --- & --- & 1.3E-02 \\
\hline
\end{tabular}

The data presented in table 1were calculated for the different systems, from the Bode plots obtained from the EIS evaluation by using the circuit presented in Figure 4 . These values were used for the determination of the capacitance of each system (table 1). The total capacitance was calculated from the following Equation 1:

$$
C=\frac{1}{2 \pi f m R}
$$

where $C$ represents the capacitance, $R$ the resistance and fm the frequency at a maximum observed. The capacitance values obtained for the different systems (table 1) revealed and suggests a charge in storage capacity for the coating condition. The capacitance obtained for the nylon/ $\mathrm{H}_{2} \mathrm{~T}(p-$ $\left.\mathrm{NH}_{2}\right) \mathrm{PP}(100 \mathrm{mg}) / \mathrm{GO}$ system presents higher values, therefore greater charge storage, which could be appropriate for diverse applications as it is proposed here.

The capacitance values obtained for the different systems (table 1) suggest a loaded storage capacity for the coating. The capacitance obtained for the nylon/ $\mathrm{H}_{2} \mathrm{~T}\left(\mathrm{p}-\mathrm{NH}_{2}\right) \mathrm{PP}(100 \mathrm{mg}) / \mathrm{GO}$ system has the highest values, therefore, higher charge storage.

\subsection{Specific capacitance.}

\subsubsection{Electrode Impedance on carbon cloth.}

The impedance result of the nylon/ $\mathrm{H}_{2} \mathrm{~T}\left(\mathrm{p}-\mathrm{NH}_{2}\right) \mathrm{PP} / \mathrm{GO}$ electrode elaborated on a substrate of carbon cloth is observed in Figure 5by a Nyquist diagram, in which a decrease in the resistance with respect to the blank can clearly be observed, as well as the presence of two time constants are observed, the first due to the coating and the second to the capacitance double layer, followed by a diffusion process at low frequencies. 


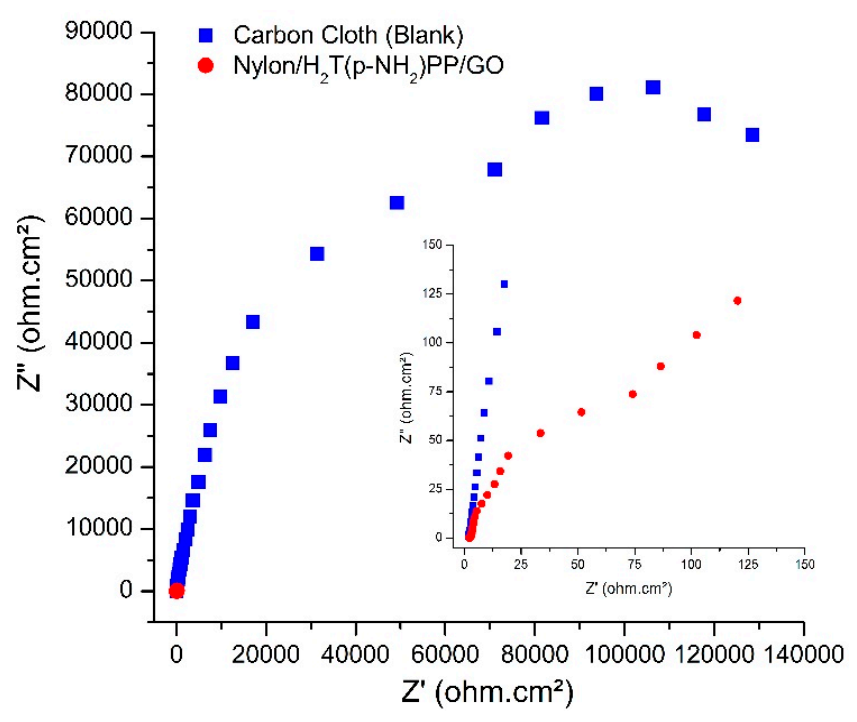

Figure 5. Electrochemical impedance of the nylon/ $\mathrm{H}_{2} \mathrm{~T}\left(\mathrm{p}-\mathrm{NH}_{2}\right) \mathrm{PP} / \mathrm{GO}$ compound deposited on carbon cloth.

\subsubsection{Cyclic Voltammetry of carbon cloth electrodes.}

With this test the specific capacitance of the nylon/ $\mathrm{H}_{2} \mathrm{~T}\left(\mathrm{p}-\mathrm{NH}_{2}\right) \mathrm{PP} / \mathrm{GO}$ compound was determined (Fig. 6), through the current originated by an electron transfer reaction, which occurs on the surface of the electrode as a function of applied potential.

Figure 6 shows the study of the specific capacitance with respect to a potential range applied for the nylon/ $\mathrm{H}_{2} \mathrm{~T}\left(\mathrm{p}-\mathrm{NH}_{2}\right) \mathrm{PP} / \mathrm{GO}$ compound, which has a capacitive voltammetric response. Likewise, it can be seen that the specific capacitance is a function of the sweep rate; at lower scan rates, higher specific capacitance values were obtained for this system, because at a lower sweep rate, there is enough time for the phenomena to manifest itself and be revealed such as: charge and mass transfer, which take place in the double electrochemical layer, present between the electrolyte and the surface of the electrode. 


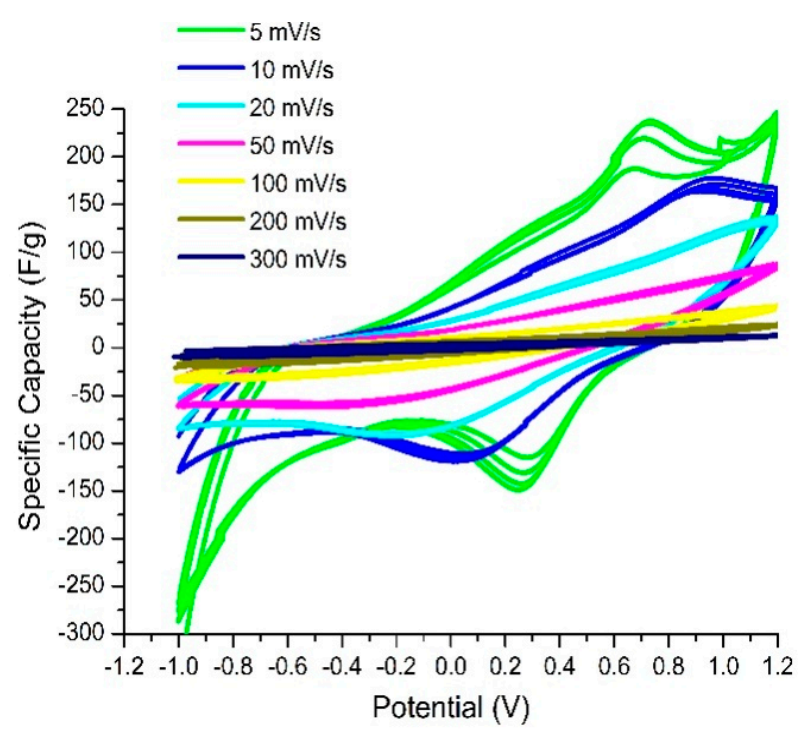

Figure 6.Cyclic voltammetry of nylon/ $\mathrm{H}_{2} \mathrm{~T}\left(\mathrm{p}-\mathrm{NH}_{2}\right) \mathrm{PP} / \mathrm{GO}(80 \% \mathrm{GO})$ compound: at different scan rates.

\section{Discussion.}

According to the electrochemical impedance measurements obtained, the overall or total impedance values increased with the different nylon/GO coatings present over the metal surface. This suggests that metal dissolution is diminished, as expected. In fact, the charge transfer resistance increased in the presence of almost all the different coating combinations formed during the experimental procedures [23]. Different nylon/GO compounds are compared, and it can be seen that the concentration of $\mathrm{GO}$ and the electrospinning times are factors slightly affecting the changes in the system response. Dispersion in data observed, suggest complex overall electrochemical reactions taking place in the film-metal interphase (mid and lower frequencies), resulting in the promotion of a barrier effect $[1,27]$. This is also reflected in the capacitance values obtained and presented in table 1.

The effect of porphyrin present in the coating, reduced the total impedance to stainless steel values, suggesting porphyrin promote metal dissolution, decreasing the effect of the coating as a physical barrier. Even though, pore resistance values are low, reflecting the type of coating formed using the electrospinning coating application. This is due to the formation of a porous but intricate coating layer of fibers as a barrier. Low electrospinning times of nylon/porphyrin coating formation present an ionic effect, while longer times suggest a physical barrier coating effect. The combined presence of GO and porphyrins, in combination with electrospinning times present variable behavior in the impedance data obtained (table 1). This is possibly due to the difficulty of aggressive species diffusing through the tortuous coating paths, because of the physical barrier of the nylon and GO, and the electrical property of the porphyrins and GO that maintain the aggressive hydrogen ions over the surface, making difficult to reach the substrate [27, 28].Characterization results show that the spatial position of amine groups of the porphyrins has important structural and textural effect on nylon and porphyrins integrated into the fibers.

In recent investigations proton permeability of graphene was proposed [26].To reduce this barrier and increase permeability, graphene can be coated with a discontinuous layer of some catalytic metal (platinum), which acts as a catalyst for the passage of hydrogen ions [26]. This same 
phenomenon is observed in the tests of the nylon/ $\mathrm{H}_{2} \mathrm{~T}\left(\mathrm{p}-\mathrm{NH}_{2}\right) \mathrm{PP} / \mathrm{GO}$ system due to the synergistic action between the $\mathrm{GO}$ and $\mathrm{H}_{2} \mathrm{~T}\left(\mathrm{p}-\mathrm{NH}_{2}\right) \mathrm{PP}$ structure, where porphyrin acts as a catalyst to the passage of protons through the coating, as seen in the schematic representation of Figure 7. Another phenomenon that reinforces the theoretical explanation is the reduction of the total impedance about 2 orders of magnitude with respect to the blank as proposed in the diagram (Fig. 7), indicating the greatly increased ionic conductivity of the system. The voltammetric results obtained also suggest a slow reaction process taking place that is reflected in the specific capacitance properties of the coating formed.

As it is well known, porphyrin macro-cycles are tetra-dentate form complexes with most metals [28].The number and spatial position of the amine groups $\left(-\mathrm{NH}_{2}\right)$ at the ortho- and parapositions of phenyls of tetraphenyl porphyrins, incorporated during polymerization can produce different modified nylon networks. The use of different species apparently induces the formation of a more homogeneous but rougher porous matrix than that of the $\mathrm{H}_{2} \mathrm{~T}\left(o-\mathrm{NH}_{2}\right) \mathrm{PP}$ species. The existence of four central nitrogens in the porphyrin macro-cycle makes the synthesis of metal complexes possible; these systems are suitable to be used with other cations such as transition metals for different applications such as electrochemical or supercapacitors $[1,27,28]$.

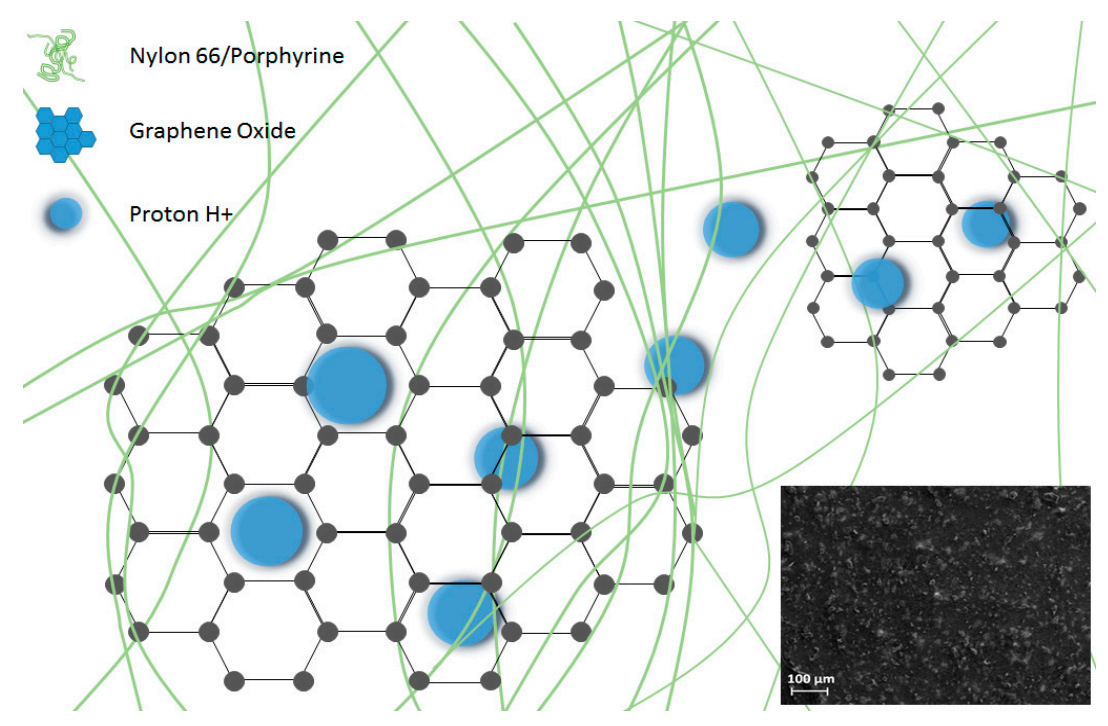

Figure 7. Schematic representation of the passage of protons through nylon/ $\mathrm{H}_{2} \mathrm{~T}\left(\mathrm{p}-\mathrm{NH}_{2}\right) \mathrm{PP} / \mathrm{GO}$ compound.

\section{Conclusions.}

Compounds nylon/ $\mathrm{H}_{2} \mathrm{~T}\left(p-\mathrm{NH}_{2}\right) \mathrm{PP}$ and nylon/GO with approximately $10^{9} \mathrm{ohm} . \mathrm{cm}^{2}$ values of total impedance, exhibit good properties as an anticorrosive coating on stainless steel in an acid environment.

The proton permeability was determined qualitatively through the nylon/ $\mathrm{H}_{2} \mathrm{~T}\left(\mathrm{p}-\mathrm{NH}_{2}\right) \mathrm{PP}$ and nylon/GO compounds by the EIS technique, as well as the reduction of the total impedance, increasing its permeability by mixing the two species and forming the compound nylon/ $\mathrm{H}_{2} \mathrm{~T}(\mathrm{p}-$ $\left.\mathrm{NH}_{2}\right) \mathrm{PP} / \mathrm{GO}$; acting $\mathrm{H}_{2} \mathrm{~T}\left(\mathrm{p}-\mathrm{NH}_{2}\right) \mathrm{PP}$ as a catalyst to the passage of the hydrogen ions.

Lower resistance, good ionic conductivity and capacitive properties which presents nylon/ $\mathrm{H}_{2} \mathrm{~T}\left(p-\mathrm{NH}_{2}\right) \mathrm{PP} / \mathrm{GO}$ compound, make it attractive for different technological developments and applications. 


\section{References.}

1. Menchaca-Campos, C.; García-Pérez, C.; Castañeda, I.; García-Sánchez, M. A.; Guardián, R.; Uruchurtu, J. Nylon/Graphene Oxide Electrospun Composite Coating. J. of Polymer Science, 2013, 2013, pp. 1-9, DOI. 101155/2013/621618.

2. Licona-Sánchez, TdeJ.; Álvarez-Romo, G. A.; Mendoza-Huizar, L. H.; Galán-Vidal, C. A.; PalomarPardavé, M.; Romero-Romo, M.; Herrera-Hernández, H.; Juárez-García, J. M.; Uruchurtu, J. Nucleation and Growth Kinetics of Electrodeposited Sulfate-Doped Polypyrrole: Determination of the Diffusion Coefficient of $\mathrm{SO}_{4}{ }^{2-}$ in the Polymeric Membrane. J. Phys. Chem. B, 2010, 114, pp. 9737-9743.DOI. 10.1021/jp102676q.

3. Wang, H.; Turner, J. A. Ferritic stainless steels as bipolar plate material for polymer electrolyte membrane fuel cells. J. Power Sources, 2004, 128, pp. 193-200.DOI. 10.1016/j.jpowsour.2003.09.075.

4. Mehta,V.; Cooper, J.S. Review and analysis of PEM fuel cell design and manufacturing. J. Power Sources, 2003, 144, pp. 32-53.DOI: 10.1016/S0378-7753(02)00542-6.

5. Borup, R.; Vanderborgh, N. Design and Testing Criteria for Bipolar Plate Materials for Pem Fuel Cell Applications.MRS. Proc. 1995, 393, pp.151-155.DOI.10.1557/PROC-393-151.

6. Woodman, A.S.; Anderson, E.B.; Jayne, K.D.; Kimble, M.C. Development of corrosion-resistant coatings for fuel cell bipolar plates. AESF SUR/FIN '99 Proceeding, vol. 6, American Electroplater and Surface Finishers Society, 1999, 6, pp. 21-24.

7. Nomoto, S.; Nakata, H.; Yoshioka, K.; Yashida, A.; Yoneda, A. Development of effective power supply using electric double layer capacitor for static magnetic field coils in fusion plasma experiments. J. Power Sources, 2001, 97, pp. 807-811. DOI. 10.1016/S0378-7753(01)00612-7.

8. Obreja, V. V. N. On the performance of supercapacitors with electrodes based on carbon nanotubes and carbon activated material-A review. Physica E, 2008, 40, pp. 2596-2605. DOI. 10.1016/j.physe.2007.09.044.

9. Wu, F. C.; Tseng, R. L.; Hu, C. C.; Wang, C. C. Physical and electrochemical characterization of activated carbons prepared from firewoods for supercapacitors. J. Power Sources, 2004, 138, pp. 351-359.DOI. 10.1016/j.jpowsour.2004.06.023.

10. Kierzek, K.; Frackowiak E.; Lota, G.; Gryglewicz, G.; Machnikowski, Electrochemical capacitors based on highly porous carbons prepared by $\mathrm{KOH}$ activation. J.Electrochim. Acta, 2004, 49, pp. 515-523. DOI. 10.1016/j.electacta.2003.08.026.

11. Barbieri, O.; Hahn, M.; Herzog, A.; Kotz, R. Carbon, Capacitance limits of high surface area activated carbons for double layer capacitors. 2005, 43, pp. 1303-1310.DOI. 10.1016/j.carbon.2005.01.001.

12. Wang, H.; Yoshio, M.; Thapa, A.K.; Nakamura, H. From symmetric AC/AC to asymmetric AC/graphite, a progress in electrochemical capacitors. J. Power Sources, 2007, 169, pp. 375-380.DOI. 10.1016/j.jpowsour.2007.02.088.

13. Ruiz, V.; Blanco, C.; Raymundo-Pinero, E.; Khomenko, V.; Beguin, F.; Santamaria, R. Effects of thermal treatment of activated carbon on the electrochemical behaviour in supercapacitors. Electrochim. Acta, 2007, 52, pp. 4969-4973. DOI. 10.1016/j.electacta.2007.01.071.

14. K. W. Nam, W. S. Yoon, K. B. Kim. X-ray absorption spectroscopy studies of nickel oxide thin film electrodes for supercapacitors. Electrochim. Acta, 2002, 47, pp. 3201-3209. DOI. 0013-4686(02)00240-2.

15. Kudo, T.; Ikeda, Y.; Watanabe, T.; Hibino, M.; Miyayama, M.; Abe, H.; Kajita, K. Amorphous $V_{2} \mathrm{O}_{5} /$ carbon composites as electrochemical supercapacitor electrodes. Solid State Ionics, 2002, 152-153, pp. 833-841.DOI. 10.1016/S0167-2738(02)00383-1.

16. Jeong, Y. U.; Manthiram, A. Nanocrystalline Manganese Oxides for Electrochemical Capacitors with Neutral Electrolytes. J. Electrochemical Soc, 2002, 149, pp. A1419-A1422. DOI. 10.1149/1.1511188.

17. Reddy, R.N.; Reddy R.G. Sol-gel $\mathrm{MnO}_{2}$ as an electrode material for electrochemical capacitors. J. Power Sources, 2003, 124, pp. 330-337. DOI. 10.1016/S0378-7753(03)00600-1.

18. Zhang, Z.J.; Chen, X.Y.; Wang, B.N.; Shi, C.W. Hydrothermal synthesis and self-assembly of magnetite $\left(\mathrm{Fe}_{3} \mathrm{O}_{4}\right)$ nanoparticles with the magnetic and electrochemical properties. J. Cryst. Growth 2008, 310, pp. 5453-5457.DOI.10.1016/j.jcrysgro.2008.08.064. 
19. Lin, Y. R.; Teng, H. A novel method for carbon modification with minute polyaniline deposition to enhance the capacitance of porous carbon electrodes. Carbon 2003, 41, pp. 2865-2871.DOI. 10.1016/S00086223(03)00424-X.

20. Zhang, J.; Kong, L. B.; Wang, B.; Luo, Y. C.; Kang, L. In-situ electrochemical polymerization of multiwalled carbon nanotube/polyaniline composite films for electrochemical supercapacitors. Synth. Met., 2009, 159, pp. 260-266. DOI. 10.1016/j.synthmet.2008.09.018.

21. Popov, B. N.; Alwohaibi, M. A.; White, R. E. Using Electrochemical Impedance Spectroscopy as a Tool for Organic Coating Solute Saturation Monitoring. J. Electrochem. Soc., 1993, 140, pp. 947-951. DOI. 10.1149/1.2056233.

22. Oestergaard, M. J. L.; Visgaard, A.; Maahn, E. AC-impedance measurements on coatings for desulphurisation plants. Surf. Coat. Int., 1993, 76, pp. 29-30. ISSN: 1356-0751/JOCCAB.

23. Xiao, H.; Mansfeld, F. Evaluation of Coating Degradation with Electrochemical Impedance Spectroscopy and Electrochemical Noise Analysis. J. Electrochem. Soc., 1994, 141, pp. 2332-2337. DOI. 10.1149/1.2055121.

24. García-Pérez, C.; Menchaca-Campos, C.; García-Sánchez, M. A.; Pereyra-Laguna, E.; Rodríguez-Pérez, O.; Uruchurtu-Chavarín, J. Nylon/Porphyrin/Graphene Oxide Fiber Ternary Composite, Synthesis and Characterization. Open Journal of Composite Materials, 2017, 7, pp. 146-165. DOI: 10.4236/ojcm.2017.73009.

25. Murray, J. N. and Hack H. P. Testing Organic Architectural Coatings in ASTM Synthetic Seawater Immersion Conditions Using EIS. Corrosion, 1992, 48, pp. 671-685, DOI: 10.5006/1.3315988.

26. Hu, S.; Lozada-Hidalgo, M.; Wang, F. C.; Mishchenko, A.; Schedin, F.; Nair, R. R.; Hill, E. W.; Boukhvalov, D. W.; Katsnelson, M. I.; Dryfe, R. A. W.; Grigorieva, I. V.; Wu, H. A.; Geim, A. K. Proton transport through one atom thick crystals. Nature, 2014, 516, pp. 227-230, DOI. 10.1038/nature14015.

27. Menchaca-Campos, C.; García-Pérez, C.; García-Sánchez, M. A.; Uruchurtu, J. EIS Evaluation and Synthesis Nylon/Graphene Oxide Electrospun Composite Coating. In ECS Meeting Abstracts, The Electrochemical Society, Mexico, August 2014. 28, pp. 1577. ISSN: 2151-2041.

28. Díaz-Alejo, L. A.; Menchaca-Campos, E. C.; Uruchurtu Chavarín, J.; Sosa-Fonseca, R.; García-Sánchez, M. A. Effects of the Addition of Ortho-and Para- $\mathrm{NH}_{2}$ Substituted Tetraphenyl porphyrins on the Structure of Nylon 66. Int. J. of Polymer Science, 2013.ID 3238542, pp. 1-14, DOI. 10.1155/2013/323854. 